\title{
Site index in relation to edaphic variables in stone pine (Pinus pinea L.) stands in south west Spain
}

\author{
Andrés BRAVO-OVIEDO ${ }^{\mathrm{a}, \mathrm{b} *}$, Gregorio MONTERO ${ }^{\mathrm{a}}$ \\ a Forest Research Centre (CIFOR-INIA), Ctra. A Coruña, km. 7,5, 28040 Madrid, Spain \\ b Current address: Universidad de Valladolid, Dpto, Producción Vegetal y Recursos Forestales, Avda. Madrid s/n Edificio E, 34004 Palencia, Spain
}

(Received 30 July 2003; accepted 19 April 2004)

\begin{abstract}
In this study, the capacity of contingency tables and correspondence analysis (CA) to determine graphically what categories of edaphic variables vary with Site Index (SI) is analysed. The categories that show association with SI are those related to textural type and water holding capacity. Furthermore, 66 discriminant rules are tested for their ability to classify plots into SI classes using edaphic data. A discriminant rule for classifying observations into two SI classes according to elevation and soil texture (represented by the silt and clay content) is presented for stone pine (Pinus pinea L.). This model was chosen based on a cross-validation. The error rate was $29.4 \%$ for the best quality group and $21.7 \%$ for the lowest quality group.
\end{abstract}

correspondence analysis / discriminant analysis / site index / edaphic variable / categorical data / Pinus pinea L.

Résumé - Site index en relation avec les variables du sol pour les peuplements de pin pignon (Pinus pinea L.) dans le sud-ouest de l'Espagne. On a étudié l'intérêt des tables de contingence et l'analyse de correspondance pour définir, d'une façon graphique, quelles sont les variables du sol les plus reliées aux caractéristiques des stations. Les variables qui sont corrélées avec SI (site index) sont celles qui sont en relation avec le type de texture et la capacité de rétention en eau. Différentes équations discriminantes basées sur des données édaphologiques ont été testées pour classer les parcelles selon la qualité de station. L'équation discriminante résultante pour le sud-ouest de l'Espagne est basé sur l'altitude et la teneur en limon et argile. L'erreur totale a été de $29,4 \%$ dans le cas de la meilleure qualité et de $21,7 \%$ dans le cas de la qualité la moins bonne.

table de contingence / analyse de correspondance / analyse discriminante / site index / variable du sol / Pinus pinea L.

\section{INTRODUCTION}

Stone pine (Pinus pinea L.) is one of the most important Mediterranean species. It is distributed extensively along the Mediterranean coast as well as in Portugal and is widespread throughout Spain in general, where it occupies approximately 475000 ha [37], which is over $70 \%$ of its world-wide distribution. The species can be found in both natural and reforested stands. Several research projects have been oriented towards aspects such as cone production, general silviculture [11, 14, $21,37,53,54]$, or the traditional role of stone pine as a sand dune fixer [52]. Timber production and growth modelling have also been investigated by researchers in recent years $[8,9,20$, 37].

Once the dunes have been stabilised in south west Spain, new harvesting opportunities begin to arise and it becomes necessary to assess site index class, understood as potential productivity, in order to apply proper silvicultural treatments.
Therefore, site index estimation has been carried out by using dominant height-base age relations, (dominant height is the average height of the 100 thickest stems per hectare [2]) and curves for this purpose have been developed in the study area using the classical guide-curve method [38], although new methods such as difference equations curves have become more popular [8].

Site index curves are appropriate for estimating site productivity where age is close to the base age. However, in young stands it is important to determine site index with regard to the kind of silvicultural treatment that should be applied in order to achieve optimal production at rotation age. Moreover, if the potential productivity of a site can be determined prior to plantation, the planted species can be selected appropriately.

Site index, defined as "all environmental factors that affect the biotic community" [17], has been evaluated using edaphic and climatic variables, especially for highly productive species such as Populus tremuloides Michx., Pseudotsuga menziessii

\footnotetext{
*Corresponding author: abravo@pvs.uva.es
} 


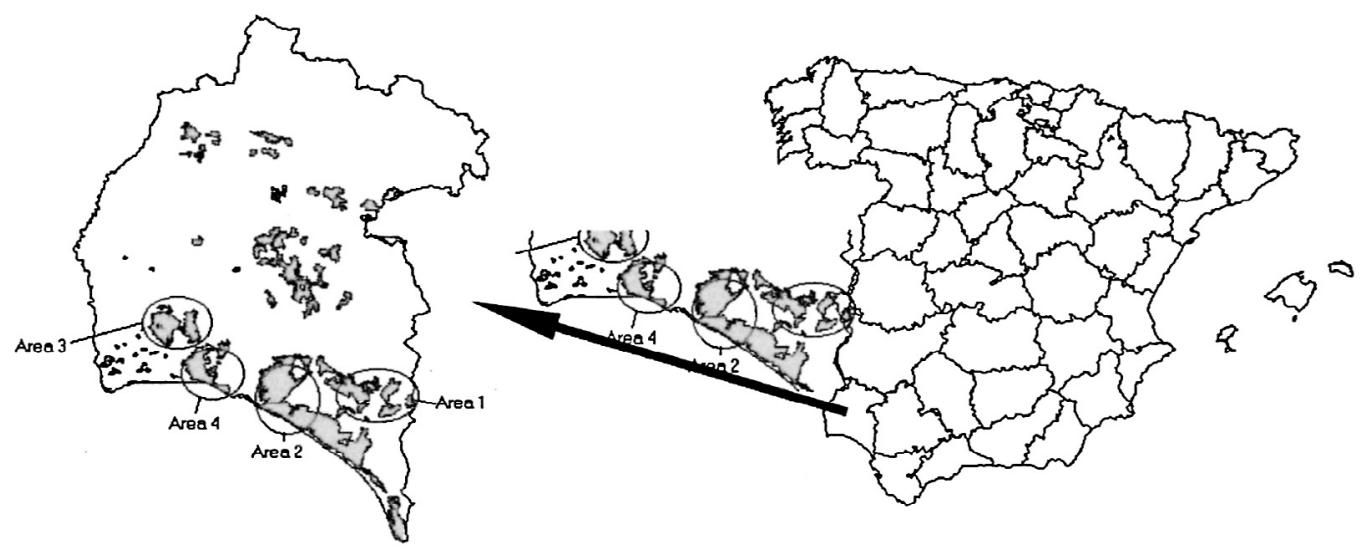

Figure 1. Study area.

Mirb. (Franco) or Picea glauca (Moench) Voss. In the majority of cases these studies have developed linear relations but the results are sometimes poor when using habitat type, precipitation or phisiographic variables or soil nutrient status as descriptors $[16,35]$. On the other hand by stratifying the study area according to biogeoclimatic regions $[13,31]$ or soil moisture regimes [51], correlations over $80 \%$ have been found. In south west Europe, site index estimation from edaphic variables has been based on correlation analysis [19] and multiple regression analysis in Pinus pinaster Ait. stands. The analysis considers edaphic [4], climate regimens, topographic attributes and lesser vegetation [40]. Recently, Bravo and Montero [7], presented a discriminant rule for site index using soil attributes such as silt, clay and cationic exchange coefficient with a $36.6 \%$ error rate for four site classes in Scots pine (Pinus sylvestris L.) stands. Sánchez-Rodríguez et al. [44], applied principal component analysis and multiple regression between site index and soil properties and tree nutritional status in Pinus radiata D. Don. stands and found a correlation of $82 \%$.

The aim of this study is to determine which edaphic variables, or categories of these variables, work as predictors of potential productivity in stone pine stands growing in sandy areas. The pattern of variation with site index is analysed, in a qualitative way, using results from a contingency table approach and graphics obtained in Correspondence Analysis (CA). Then, a discriminant rule is applied to classify observations into different site index classes. Finally, an evaluation is carried out to verify if the discriminant analysis uses the same variables as the CA.

\section{MATERIALS AND METHODS}

\subsection{Data}

In a previous study [36], four zones (Fig. 1) in south Huelva were delimited according to productivity, age and density, covering an area equal to 45000 ha.

- Area 1: East inland;

- Area 2: East shore;

- Area 3: West inland;

- Area 4: West shore.
Within each of these areas a $50 \mathrm{~cm}$ pit was dug in ten plots with similar geological and silvicultural features. In each pit, the following variables were recorded for the whole profile and for the first horizon, where most of the roots were found: reaction, available nitrogen, available phosphorus, available potassium, carbon nitrogen ratio and percentage of sand, clay and silt. The Compactness Capacity Coefficient (CCC) and Silt Impermeability Coefficient (SIC) were calculated according to Nicolás and Gandullo [39]. Table I shows descriptive statistics for the variables studied as well as for elevation.

Four site classes (I = $18 \mathrm{~m}, \mathrm{II}=15 \mathrm{~m}, \mathrm{III}=12 \mathrm{~m}, \mathrm{IV}=9 \mathrm{~m}$ ) based on site index (base age 75 years) were defined according to site index curves developed by Montero and Ruiz-Peinado [38]. The plots were assigned to a site index class resulting in 6 plots for class I, 11 for class II, 18 for class III and 5 for class IV. The goal is to classify new observations into one of these four classes. However, classes I and II were grouped together, as well as classes III and IV in order to compare results. This was done because extreme classes had few plots.

\subsection{Statistical methods}

The association between soil attributes and site index at a site with low soil variability is first evaluated using a contingency table approach, where the variables must be categorized into groups and cross tabulated. Three to five categories were established for the variables. A test of category separation was not performed due to the small range of variation between each category. Textural type grouping was done according to the Gandullo and Sánchez-Palomares [19] classification, which is a modification of the USDA texture triangle for Spanish pine stands, that results in five textural types according to soil clay, silt and sand content. Nitrogen grouping was based on Cobertera, [15]. Permeability was calculated on the principle that soil aeration counters the possibility of pooling due to compacting (as measured by the Compactness Capacity Coefficient (CCC)) and microporosity (as measured by the Silt Impermeability Coefficient (SIC)) [39]. Table II shows the categories and variation ranges for each edaphic variable. Those categorized variables that show a relationship to site quality classes are displayed using Correspondence Analysis. STATISTICA package [47] was used to perform contingency and correspondence analysis.

Finally, a discriminant rule is developed to classify the observations (plots) into site qualities according to its soil properties. The variables included in each analysis are compared. PROC DISCRIM of SAS [45] was used for the discriminant analysis. Contingency and discriminant analysis are better known techniques than correspondence analysis so special emphasis on the explanation of this technique is done below. 
Table I. Descriptive statistics and units of variables studied.

\begin{tabular}{|c|c|c|c|c|c|c|}
\hline Variable & Units & $N$ & Average & Minimum & Maximun & Std. deviat. \\
\hline $\mathrm{N}$ & $\%$ organic & 40 & 0.04 & 0.02 & 0.28 & 0.04 \\
\hline $\mathrm{P}$ & ppm & 40 & 3.30 & 0.00 & 10.50 & 2.41 \\
\hline K & ppm & 40 & 35.38 & 8.20 & 100.92 & 21.70 \\
\hline $\mathrm{N}_{1 \mathrm{~h}}$ & $\%$ organic & 40 & 0.07 & 0.02 & 0.82 & 0.13 \\
\hline $\mathrm{P}_{1 \mathrm{~h}}$ & ppm & 40 & 3.28 & 0 & 14.00 & 2.74 \\
\hline $\mathrm{K}_{1 \mathrm{~h}}$ & ppm & 40 & 43.68 & 5.00 & 166.60 & 31.96 \\
\hline $\mathrm{OM}$ & $\%$ oxidable & 40 & 0.61 & 0.10 & 2.50 & 0.47 \\
\hline $\mathrm{OM}_{1 \mathrm{~h}}$ & $\%$ oxidable & 40 & 1.19 & 0.09 & 4.10 & 0.81 \\
\hline $\mathrm{C} / \mathrm{N}$ & & 40 & 9.27 & 1.85 & 18.17 & 3.26 \\
\hline $\mathrm{C} / \mathrm{N}_{1 \mathrm{~h}}$ & & 40 & 13.11 & 0.95 & 20.57 & 4.64 \\
\hline $\mathrm{TF}$ & $\%$ & 40 & 84.36 & 23.00 & 100.00 & 22.92 \\
\hline Clay & $\%$ & 40 & 12.57 & 1.40 & 34.20 & 9.46 \\
\hline Sand & $\%$ & 40 & 76.88 & 41.68 & 96.34 & 14.91 \\
\hline Silt & $\%$ & 40 & 10.58 & 0.86 & 30.76 & 7.47 \\
\hline GRU & $\%$ & 40 & 15.65 & 0.00 & 77.00 & 22.93 \\
\hline WHC & $\mathrm{mm}$ & 40 & 191.59 & 60.40 & 330.20 & 81.28 \\
\hline $\mathrm{CCC}$ & & 40 & 0.15 & 0.00 & 0.66 & 0.17 \\
\hline SIC & & 40 & 0.08 & 0.01 & 0.21 & 0.04 \\
\hline $\mathrm{pH}$ & & 40 & 6.16 & 5.20 & 7.77 & 0.53 \\
\hline ELV & $\mathrm{m}$ & 40 & 72.88 & 35.00 & 127.00 & 27.70 \\
\hline
\end{tabular}

$\mathrm{N}$ : Nitrogen, P: Phosphorus, K: Potassium, $\mathrm{N}_{1 \mathrm{~h}}$ : Nitrogen in first horizon, $\mathrm{P}_{1 \mathrm{~h}}$ : Phosphorus in first horizon, $\mathrm{K}_{1 \mathrm{~h}}$ : Potassium in first horizon, OM: Organic matter, $\mathrm{OM}_{1 \mathrm{~h}}$ : Organic matter in first horizon, $\mathrm{C} / \mathrm{N}$ : Carbon-nitrogen ratio, $\mathrm{C} / \mathrm{N}_{1 \mathrm{~h}}$ : Carbon-nitrogen ratio in first horizon, TF: Fines, GRU: Gross material, WHC: Water holding capacity, CCC: Compactness capacity coefficient, SIC: Silt impermeability coefficient, ELV: Elevation.

\subsubsection{Contingency analysis}

Categories of edaphic variables and site index are cross tabulated in a two-way contingency table of $r \times c$ order as is shown in Table III. The independence of categories in a contingency table is studied by comparing the observed chi-squared to the value expected for alpha $=0.05$. Cramer's V is calculated to compare the association between categories in the contingency table. The association between ecological attributes categories and site index classes is tested with this statistic, that ranges from 0 (no association) to 1 (perfect association), regardless of the order in the table [42]

$$
V=\sqrt{\frac{\chi^{2}}{N \cdot t}}
$$

where $\chi^{2}$ is the chi-squared statistic, $N$ is the number of observations and $t$ is the smallest value of $(r-1)$ or $(c-1), r$ is the number of rows and $c$ is the number of columns.

Only those two-way tables where the null hypothesis of independence was rejected will be further analysed using correspondence analysis (CA) to represent the association graphically.

\subsubsection{Correspondence analysis}

Correspondence analysis is an ordination technique called "indirect gradient analysis" that consists of ordination followed by environmental gradient identification [48]. It can also be used for displaying association in a data matrix $[1,24]$ in order to assess the association between columns and/or rows [25]. The data matrix may take the form of a two-way contingency table as shown in Table III.
From Table III several matrices may be interpreted in order to understand how CA works $[24,32]$. Symbols will be the same as in Table III or explained otherwise.

First, the data matrix $\mathbf{N}$

$$
\mathbf{N}=\left(\begin{array}{lllllll}
n_{11} & \ldots & \cdots & n_{1 j} & \cdots & \cdots & n_{1 c} \\
\vdots & \ddots & & \vdots & \ddots & & \vdots \\
\vdots & & \ddots & \vdots & & \ddots & \vdots \\
n_{i 1} & \ldots & \cdots & n_{i j} & \ldots & \cdots & n_{r c}
\end{array}\right)
$$

and correspondence or relative frequencies matrix $\mathbf{F}$

$\mathbf{F}=\left(\begin{array}{llllllr}f_{11} & \ldots & \ldots & f_{1 j} & \ldots & \ldots & f_{1 c} \\ \vdots & \ddots & & \vdots & \ddots & & \vdots \\ \vdots & & \ddots & \vdots & & \ddots & \vdots \\ f_{i 1} & \ldots & \ldots & f_{i j} & \ldots & \ldots & f_{r c}\end{array}\right) \quad \mathbf{F}=\left[f_{i j}\right]=\frac{1}{n_{\bullet}} \mathbf{N}$

where $f_{i j}$ is the relative frequency of site index class $i$ found in category $j$.

Next, the sum of the vectors of columns $\mathbf{c}$ and rows $\mathbf{r}$ are defined as:

$$
\mathbf{r}=\mathbf{F} 1 \quad \mathbf{c}=\mathbf{F}^{\prime} \mathbf{1}
$$


Table II. Categories for Correspondence Analysis and range of variation.

\begin{tabular}{|c|c|c|c|c|c|}
\hline \multirow[t]{2}{*}{ Variable } & \multicolumn{5}{|c|}{ Categories } \\
\hline & A & B & $\mathrm{C}$ & $\mathrm{D}$ & $\mathrm{E}$ \\
\hline $\mathrm{N}_{1 \mathrm{~h}}$ & $\geq 0.4$ & {$[0.2-0.4)$} & {$[0.1-0.2)$} & {$[0.02-0.1)$} & $<0.02$ \\
\hline K & $\geq 100$ & {$[75-100)$} & {$[50-75)$} & {$[25-50)$} & $<25$ \\
\hline \multirow[t]{2}{*}{$\mathrm{K}_{1 \mathrm{~h}}$} & $\geq 100$ & {$[75-100)$} & {$[50-75)$} & {$[25-50)$} & $<25$ \\
\hline & A & B & $\mathrm{C}$ & $\mathrm{D}$ & \\
\hline WHC & $\geq 300$ & {$[200-300)$} & [100-200) & $<100$ & \\
\hline $\mathrm{pH}$ & $\geq 7$ & {$[6.5-7)$} & {$[6-6.5)$} & $<6$ & \\
\hline $\mathrm{OM}$ & $\geq 1.3$ & {$[1-1.3)$} & {$[0.7-1)$} & $<0.7$ & \\
\hline $\mathrm{OM}_{1 \mathrm{~h}}$ & $\geq 1.3$ & {$[1-1.3)$} & {$[0.7-1)$} & $<0.7$ & \\
\hline TF & {$[90-100)$} & {$[80-90)$} & $<80$ & & \\
\hline Clay & $\geq 30$ & {$[20-30)$} & {$[10-20)$} & $<10$ & \\
\hline Sand & (90-100] & 80-90) & {$[70-80)$} & $<70$ & \\
\hline Silt & $\geq 30$ & {$[20-30)$} & [10-20) & $0-10$ & \\
\hline GRU & $\geq 80$ & [40-80) & {$[20-40)$} & $0-20$ & \\
\hline $\mathrm{P}$ & $\geq 5$ & {$[3-5)$} & {$[1-3)$} & $<1$ & \\
\hline $\mathrm{P}_{1 \mathrm{~h}}$ & $\geq 5$ & {$[3-5)$} & {$[1-3)$} & $<1$ & \\
\hline $\mathrm{N}$ & $\geq 0.075$ & {$[0.05-0.075)$} & {$[0.025-0.05)$} & $<0.025$ & \\
\hline $\mathrm{C} / \mathrm{N}_{1 \mathrm{~h}}$ & $\geq 18$ & [14-18) & [10-14) & $<10$ & \\
\hline $\mathrm{C} / \mathrm{N}$ & $\geq 12$ & {$[8-12)$} & {$[4-8)$} & $<4$ & \\
\hline \multirow[t]{2}{*}{ Elevation } & $\geq 100$ & {$[75-100)$} & {$[50-75)$} & $<50$ & \\
\hline & A & B & $\mathrm{C}$ & & \\
\hline \multirow{2}{*}{$\begin{array}{l}\text { Permeability } \\
\text { (CCC-SIC) }\end{array}$} & 5 & 4 & 3 & & \\
\hline & A & $\mathrm{C}$ & $\mathrm{D}$ & $\mathrm{E}$ & \\
\hline \multicolumn{6}{|l|}{ Textural type } \\
\hline$\%$ Sand & $35-65$ & $50-70$ & $50-80$ & $55-80$ & \\
\hline$\%$ Lime & $25-55$ & $10-25$ & $5-25$ & 40 & \\
\hline$\%$ Clay & $10-40$ & $25-40$ & $10-25$ & $5-10$ & \\
\hline
\end{tabular}

Units and variables as in Table I.

where $\mathbf{1}$ is the vector of ones where the order depends on specific context; $\mathbf{r}$ and $\mathbf{c}$ are also called row and column masses respectively.

Now, we can calculate profile matrices for columns and rows, Pr and Pc. The profile is the relative frequency of a column or row category across a row or column category, in other words, a conditional frequency of category $\mathrm{J}($ or I $)$ for $\mathrm{I}=i($ or $\mathrm{J}=j$ ) [30]. The row and column profiles define two clouds of points [24]. The final target of CA is to discover differences in profiles and the interactions (positive or negative) between rows and columns [5].

$$
\mathbf{P r}=\mathbf{D r}^{-\mathbf{1}} \mathbf{F}=\left[\begin{array}{c}
\tilde{\mathbf{r}}_{1}^{\prime} \\
\vdots \\
\tilde{\mathbf{r}}_{i}^{\prime} \\
\end{array}\right] \quad \mathbf{P c}=\mathbf{D c}^{-\mathbf{1}} \boldsymbol{F}^{\prime}=\left[\begin{array}{c}
\tilde{\mathbf{c}}_{1}^{\prime} \\
\vdots \\
\tilde{\mathbf{c}}_{j}^{\prime} \\
\end{array}\right]
$$

where Dr and Dc are the diagonal matrices constructed from the row and column masses respectively (e.g. the diagonals elements of Dr are the elements of $\mathbf{r}), \tilde{\mathbf{r}}_{i}$ is the row profile $(i=1 \ldots \mathrm{I})$ and $\tilde{\mathbf{c}}_{j}$ is the column profile $(j=1 \ldots \mathrm{J})$.

In order to compare the cloud of points defined by the profiles of rows and columns, total inertia is required. The total inertia of rows in $(I)$ and columns $\operatorname{in}(J)$ is the overall spatial variation of each cloud of points and indicates how much the individual profiles are spread around the centroid of row and column clouds [24]. The centroid of the row cloud is equal to the vector sum of the column and vice-versa [24].

$$
\begin{aligned}
& \operatorname{in}(I)=\sum_{i} r_{i}\left(\tilde{\mathbf{r}}_{i}-\mathbf{c}\right)^{\prime} \mathbf{D c}^{-1}\left(\tilde{\mathbf{r}}_{i}-\mathbf{c}\right) \\
& \operatorname{in}(J)=\sum_{i} c_{j}\left(\tilde{\mathbf{c}}_{j}-\mathbf{r}\right)^{\prime} \mathbf{D r}^{-1}\left(\tilde{\mathbf{c}}_{j}-\mathbf{r}\right)
\end{aligned}
$$

which have the same value in both clouds, and can be written as:

$$
\operatorname{in}(I)=\operatorname{in}(J)=\left\{\left(f_{i j}-f_{i_{\bullet}} f_{\bullet j}\right)^{2} \frac{1}{f_{i_{\bullet}} f_{\bullet j}}, i \in I, j \in J\right\}=\mathbf{Q}=\left[q_{i j}\right] .
$$

The sum of elements in $\mathbf{Q}$ is the total inertia, and differs from chi-squared by a constant, so may be calculated as $\chi^{2} / n_{\text {.. }}$ [32]. The chi-squared evaluates the distance between observed and expected distributions in a contingency table [28]. According to this distance, CA creates principal axes with maximum inertia [29]. This allows us to draw a perceptual map, which shows a visual representation of the association between rows and columns. The contribution of categories to the overall chi-squared value is used as a similarity index by applying the sign of the difference between observed values and expected values [25].

\subsubsection{Discriminant analysis}

Discriminant analysis (DA) is widely used in forest science $[7,26$, 34]. DA consists of a set of linear functions of independent variables that calculates the geometrical distance between observations and established groups. Observations are classified according to the shortest distance to a group, represented by the highest value of the linear discriminant function, which are also called classification functions [22]. The number of functions is equal to the number of groups. However, if you are only determining the differences between groups, the number of discriminant functions is $g-1$, where $g$ is the number of groups. If the number of independent variables, $p$, used in the function is lower than the number of groups, then the maximum number of discriminant functions is $p$ [22]. In this paper the classification aspect of the discriminant analysis is used, so the number of classification functions presented is the same as the number of groups considered.

According to the definition of site index class [17] soil attributes and climate data determine productivity. We did not have climatic data, but elevation was included because it is related to climate and has proven its importance in soil-site studies [27].

Variables that show lack of normality $(p=0.05)$, even after applying a transformation [43], and those variables that are correlated ( $p=$ 0.05 ) were rejected in the analysis (Tabs. IV and V). We preferred to include the original variable without any transformation, so when both the original and transformed variables show normality, the former was chosen. Following the principle of parsimony, models were fitted with two or three independent variables, resulting in 66 models to be tested.

The discriminant analysis was evaluated using cross-validation. In this kind of validation, sample data are omitted one at a time, the parameters of the model are re-estimated and then the model is validated with the omitted datum. 
Table III. Contingency table.

\begin{tabular}{|c|c|c|c|c|c|c|c|}
\hline I & spl & $s p 2$ & $\ldots$ & spj & $\ldots$ & $s p c$ & Total \\
\hline$h 1$ & $n_{11}$ & $n_{12}$ & $\ldots$ & $n_{1 j}$ & $\ldots$ & $n_{1 c}$ & $n_{1}$. \\
\hline$h 2$ & $n_{12}$ & $n_{22}$ & $\ldots$ & $n_{2 j}$ & $\ldots$ & $n_{2 c}$ & $n_{2}$. \\
\hline . & . & . & . & . & . & . & . \\
\hline . & . & . & . & . & $\cdot$ & . & . \\
\hline . & . & . & . & . & $\cdot$ & . & . \\
\hline$h i$ & $n_{i 1}$ & $n_{i 2}$ & $\ldots$ & $n_{i j}$ & $\ldots$ & $n_{i c}$ & $\sum_{j=1}^{c} n_{i j}$ \\
\hline . & . & . & . & . & . & . & $\cdot$ \\
\hline . & . & . & . & . & $\cdot$ & . & . \\
\hline . & . & . & . & . & $\cdot$ & . & . \\
\hline$h r$ & $n_{i 1}$ & $n_{i 2}$ & & $n_{i j}$ & $\ldots$ & $n_{r c}$ & $n_{r}$ \\
\hline Total & $n \cdot 1$ & $\mathrm{n}_{\cdot 2}$ & $\ldots$ & $\sum_{i=1}^{r} n_{i j}$ & $\ldots$ & $n_{. c} \ldots$ & $\sum_{j=1}^{c} n_{i j}=n_{\bullet \bullet}$ \\
\hline
\end{tabular}

I and $\mathrm{J}$ are categories; spj are the categories of columns (e.g. ecological attributes such as sand content) and $h i$ are the categories of rows (e.g. site index classes); $n_{i j}$ is the number of plots in site class $i$ with category $j ; \sum_{j=1}^{c} n_{i j}$ is the row marginal distribution; $\sum_{i=1}^{r} n_{i j}$ is the column marginal distribution
and $n_{. .}$is the sum of absolute frequencies.

Table IV. Shapiro and Wilks normality test. Original and transformed variables.

\begin{tabular}{|c|c|c|c|c|c|}
\hline Variable & $X$ & $\sqrt{\mathrm{X}}$ & $\sqrt{(X+0.5)}$ & $\operatorname{Ln}(X)$ & $1 / \mathrm{X}$ \\
\hline $\mathrm{N}$ & 0.0001 & 0.0001 & 0.0001 & 0.0001 & 0.0001 \\
\hline$P$ & 0.0096 & 0.9004 & 0.7166 & 0.9004 & 0.0001 \\
\hline $\mathrm{K}$ & 0.0001 & 0.0211 & 0.0193 & 0.0193 & 0.0015 \\
\hline $\mathrm{N}_{1 \mathrm{~h}}$ & 0.0001 & 0.0001 & 0.0001 & 0.0001 & 0.295 \\
\hline $\mathrm{P}_{1 \mathrm{~h}}$ & 0.0008 & 0.0427 & 0.0713 & 0.0001 & 0.0001 \\
\hline $\mathrm{K}_{1 \mathrm{~h}}$ & 0.0001 & 0.0001 & 0.0001 & 0.0001 & 0.0001 \\
\hline $\mathrm{OM}$ & 0.0001 & 0.0019 & 0.0001 & 0.0001 & 0.0001 \\
\hline $\mathrm{OM}_{1 \mathrm{~h}}$ & 0.0001 & 0.2465 & 0.0305 & 0.0305 & 0.0001 \\
\hline $\mathrm{C} / \mathrm{N}$ & 0.3498 & 0.0346 & 0.0465 & 0.0465 & 0.0001 \\
\hline $\mathrm{C} / \mathrm{N}_{1 \mathrm{~h}}$ & 0.003 & 0.0001 & 0.0001 & 0.001 & 0.0001 \\
\hline $\mathrm{TF}$ & 0.0001 & 0.0001 & 0.0001 & 0.0001 & 0.0001 \\
\hline Clay & 0.0012 & 0.0982 & 0.0778 & 0.0648 & 0.0001 \\
\hline Sand & 0.0013 & 0.0002 & 0.0002 & 0.0002 & 0.0001 \\
\hline Silt & 0.0001 & 0.0655 & 0.0431 & 0.0655 & 0.0001 \\
\hline GRU & 0.0001 & 0.0001 & 0.0001 & 0.0001 & 0.0001 \\
\hline WHC & 0.0057 & 0.0129 & 0.0128 & 0.0128 & 0.0001 \\
\hline $\mathrm{CCC}$ & 0.001 & 0.0259 & 0.0001 & 0.0001 & 0.0001 \\
\hline SIC & 0.0847 & 0.9982 & 0.1722 & 0.1722 & 0.0001 \\
\hline $\mathrm{pH}$ & 0.2958 & 0.5047 & 0.4885 & 0.488 & 0.9305 \\
\hline ELV & 0.0011 & 0.0091 & 0.009 & 0.009 & 0.062 \\
\hline
\end{tabular}

$p$-value at 0.05 level. Variables units as in Table I. Bold values indicate variables selected. Untransformed variables (X) have been preferably selected when possible. 
Table V. Pearson's Correlation coefficient.

\begin{tabular}{|c|c|c|c|c|c|c|c|c|c|c|}
\hline & $\mathrm{pH}$ & $\sqrt{\mathrm{P}}$ & $\mathrm{C} / \mathrm{N}$ & $\sqrt{\left(\mathrm{OM}_{1 \mathrm{~h}}\right)}$ & SIC & $\sqrt{\text { clay }}$ & $\operatorname{Ln}($ silt $)$ & $1 / \mathrm{N}_{1 \mathrm{~h}}$ & $\sqrt{\left(P_{1 h}+0.5\right)}$ & $1 / \mathrm{ELV}$ \\
\hline \multirow[t]{2}{*}{$\mathrm{PH}$} & 1 & 0.2472 & -0.2704 & -0.2441 & -0.1666 & -0.4073 & -0.3524 & 0.147 & 0.1511 & 0.0476 \\
\hline & & $(0.124)$ & $(0.091)$ & (0.129) & (0.304) & $(0.009)$ & $(0.025)$ & $(0.365)$ & $(0.352)$ & $(0.770)$ \\
\hline \multirow[t]{2}{*}{$\sqrt{\mathrm{P}}$} & & 1 & -0.1398 & -0.3346 & -0.3451 & -0.1174 & -0.4495 & 0.2193 & 0.3659 & 0.233 \\
\hline & & & $(0.389)$ & (0.034) & $(0.029)$ & $(0.470)$ & $(0.003)$ & (0.173) & $(0.020)$ & (0.147) \\
\hline \multirow[t]{2}{*}{$\mathrm{C} / \mathrm{N}$} & & & 1 & 0.4569 & 0.08 & 0.0855 & 0.3592 & 0.0685 & -0.161 & 0.0647 \\
\hline & & & & (0.003) & (0.623) & $(0.600)$ & $(0.022)$ & (0.674) & (0.319) & (0.691) \\
\hline \multirow[t]{2}{*}{$\sqrt{\left(\mathrm{OM}_{1 \mathrm{~h}}\right)}$} & & & & 1 & 0.2539 & 0.3581 & 0.5219 & -0.7275 & -0.197 & 0.0175 \\
\hline & & & & & $(0.113)$ & $(0.023)$ & $(0.000)$ & $(<0.0001)$ & $(0.225)$ & (0.914) \\
\hline \multirow[t]{2}{*}{ SIC } & & & & & 1 & 0.3201 & 0.7809 & -0.2722 & -0.075 & 0.0617 \\
\hline & & & & & & $(0.044)$ & $(<0.0001)$ & $(0.089)$ & $(0.6453)$ & $(0.705)$ \\
\hline \multirow[t]{2}{*}{$\sqrt{\text { clay }}$} & & & & & & 1 & 0.5098 & -0.3439 & -0.240 & 0.0313 \\
\hline & & & & & & & $(0.000)$ & $(0.029)$ & (0.134) & (0.848) \\
\hline \multirow[t]{2}{*}{$\operatorname{Ln}($ silt $)$} & & & & & & & 1 & -0.4189 & -0.207 & 0.0773 \\
\hline & & & & & & & & $(0.007)$ & (0.197) & $(0.635)$ \\
\hline \multirow[t]{2}{*}{$1 / \mathrm{N}_{1 \mathrm{~h}}$} & & & & & & & & 1 & 0.1266 & 0.00006 \\
\hline & & & & & & & & & $(0.436)$ & $(0.999)$ \\
\hline \multirow[t]{2}{*}{$\sqrt{\left(\mathrm{P}_{1 \mathrm{~h}}+0.5\right)}$} & & & & & & & & & 1 & 0.2370 \\
\hline & & & & & & & & & & $(0.140)$ \\
\hline $1 / \mathrm{ELV}$ & & & & & & & & & & 1 \\
\hline
\end{tabular}

In parenthesis $p$-value for alpha $=0.05$.

\section{RESULTS}

\subsection{Contingency table analysis}

The results are shown in Table VI. Site index is not independent of textural type, water holding capacity (WHC), permeability, organic matter and nitrogen (both in the first horizon), $\mathrm{pH}$ and sand content. The Cramer's V association values (0.38-0.48) indicate a slight association between categories.

\subsection{Correspondence analysis}

Table VII shows similarity index values for edaphic categories found to be related to site index in the contingency analysis. Smaller values indicate a lower association. Textural type E is associated to site index class I (S-I) and II (S-II), whereas Site index class IV (S-IV) is located in textural type C, which has more clay content. When it comes to water holding capacity (WHC), S-IV is associated to category A, although the pattern is not so clear in S-I and intermediate classes.

The association between nitrogen content in the first horizon and site index is not clear, although it seems that S-I and S-II are located in sites with low nitrogen content (B and D). It is highly likely to find S-IV in areas with higher organic matter content (A).

Permeability category A is clearly associated with S-I and S-II. S-IV is associated with category B and C, which are lower permeability categories. Sand group D is associated with classes III and IV, whereas $\mathrm{pH}$ does not follow a clear pattern of variation.
Figure 2 shows perceptual maps for textural type, WHC and sand content. In all cases, this two dimensional representation accounts for more than $80 \%$ of the total inertia and site index is correctly ordinated. It is remarkable that class IV is far from the other classes, indicating that class IV is quite different from the rest.

These plots represent a qualitative tool to display the association between site index and soil attributes. In Figure $2 a$ the association between site index class IV and lower sand content, represented by type $\mathrm{D}$, is quite clear whereas Figure $2 \mathrm{~b}$ shows the relationship between site index IV and textural type $\mathrm{C}$ with more clay content. The same occurs in Figure $2 \mathrm{c}$ where high values of WHC are associated with the lowest quality. In all cases the results are consistent as first dimension ordinates the site index and state the fact that site index class IV is located in areas with low sand and high clay content that derives in high values of WHC. The association between the rest of site qualities with soil attributes is not so clear.

\subsection{Discriminant analysis}

Correspondence analysis does not allow us to determine the reason for the existence of the variation in pattern [25]. However, the identification of such a pattern is possible with the "perceptual maps". A discriminant rule is applied to verify whether variables chosen in the correspondence analysis are the same when used in the discriminant model.

Six out of 66 models fitted returned a cross-validated error lower than $50 \%$. 
Table VI. Contingency tables analysis. Bold values are not independent.

\begin{tabular}{|c|c|c|c|c|c|}
\hline Variable & Chi-squared & d.f. & Expected Chi-squared 0.95 & Ho: $p_{i j}=p_{i} \cdot p_{\cdot j}$ & Cramer's V \\
\hline $\mathrm{N}$ & 14.18 & 9 & 16.93 & NR & 0.34 \\
\hline $\mathrm{P}$ & 3.49 & 9 & 16.93 & NR & 0.17 \\
\hline K & 2.87 & 12 & 21.03 & NR & 0.15 \\
\hline $\mathrm{N}_{1 \mathrm{~h}}$ & 21.68 & 12 & 21.03 & $\mathrm{R}$ & 0.43 \\
\hline $\mathrm{P}_{1 \mathrm{~h}}$ & 14.18 & 9 & 16.93 & NR & 0.34 \\
\hline $\mathrm{K}_{1 \mathrm{~h}}$ & 11.09 & 12 & 21.03 & NR & 0.30 \\
\hline $\mathrm{OM}$ & 12.2 & 9 & 16.93 & NR & 0.32 \\
\hline $\mathrm{OM}_{1 \mathrm{~h}}$ & 17.88 & 9 & 16.93 & $\mathrm{R}$ & 0.39 \\
\hline $\mathrm{C} / \mathrm{N}$ & 16.60 & 9 & 16.93 & NR & 0.37 \\
\hline $\mathrm{C} / \mathrm{N}_{1 \mathrm{~h}}$ & 3.33 & 9 & 16.93 & NR & 0.17 \\
\hline $\mathrm{TF}$ & 11.95 & 9 & 16.93 & NR & 0.32 \\
\hline Clay & 16.21 & 9 & 16.93 & NR & 0.37 \\
\hline Sand & 26.31 & 9 & 16.93 & $\mathrm{R}$ & 0.47 \\
\hline Silt & 10.16 & 9 & 16.93 & NR & 0.29 \\
\hline GRU & 8.36 & 9 & 12.6 & NR & 0.26 \\
\hline WHC & 17.23 & 9 & 16.93 & $\mathrm{R}$ & 0.38 \\
\hline $\mathrm{pH}$ & 17.59 & 9 & 16.93 & $\mathrm{R}$ & 0.38 \\
\hline ELV & 12.39 & 9 & 16.93 & NR & 0.32 \\
\hline Textural type & 21.10 & 9 & 16.93 & $\mathrm{R}$ & 0.42 \\
\hline PERMEAB & 18.22 & 6 & 12.6 & $\mathrm{R}$ & 0.48 \\
\hline
\end{tabular}

$\mathrm{NR}$ and $\mathrm{R}$ indicates no rejection or rejection of null hypotheses (see text). $p_{i j}$ is joint probability. $p_{i} \bullet$ and $p_{\bullet j}$ are marginal probabilities.

$$
\begin{aligned}
& \text { constant }+ \text { SIC }+1 / \text { nit_1h+1/elv } \\
& \text { constant }+S I C+1 / \text { nit_1 } h \\
& \text { constant }+\operatorname{Ln}(\text { silt })+1 / e l v \\
& \text { constant }+\operatorname{Ln}\left(\text { silt }+1 / e l v+\sqrt{P_{1 h}+0.5}\right. \\
& \text { constant }+1 / \text { nit_1 } h+1 / e l v \\
& \text { constant }+1 / e l v+\sqrt{\text { clay }} .
\end{aligned}
$$

model 1

model 2

model 3

model 4

model 5

model 6

The cross-validation error rates are shown in Table VIII. When no grouping is used class I is never classified correctly. If classes I and II are grouped, the best model is 3. Class IV is classified better with model 6 when no grouping is done or when class I and class II are grouped. When classes III and IV are grouped, model 6 gives the lowest overall error $(32.5 \%)$, although the lowest error for group III + IV is found in models 2 and $5(4.3 \%)$. When class I and class II are grouped, as well as class III and class IV, model 3 had the best partial and overall error. These results indicate that site quality is connected to clay and silt content, as was found in the correspondence analysis. To analyse the joint effect of silt and clay, a model with these two variables was tested (model 7).

$$
\text { constant }+1 / \text { elv }+\sqrt{\text { clay }}+\operatorname{Ln}(\text { silt }) .
$$

model 7

This model does not improve the overall error when quality I and II are grouped and likewise quality III and IV are grouped ( $25 \%)$, but the distribution of errors is better, that is, the model classifies the groups considered in a homogenous way. Figure 3 shows the percentages of classification into the correct group, the adjacent group and the non-adjacent group for models 3 and 7 .

When no site class grouping is applied, models 3 and 7 classify $16.67 \%$ of site index class I observations into site index class II, and the rest into the third class. The rest of the qualities are classified correctly or into adjacent groups. Quality IV is classified better by model 7 and the intermediate qualities are classified better by model 3 .

When classes I and II are grouped, the percentage of correct classification increases to $82.35 \%$ with model 7 , whereas class III classification is better with model 3. The classification percentages for class IV remain unaltered.

The best results are obtained from both models when classes III and IV are grouped (91.3\% correct classification). The best classification rate occurs when site quality classes I and II, and classes III and IV are grouped $(70.59 \%$ and $78.26 \%$ respectively in model 7).

Table IX shows the discriminant rule for two groups (I + II, and III + IV) defined by model 7.

\section{DISCUSSION}

Anamorphic site index curves have been widely used to determine site index class in even-aged stands and are an important tool in forest management. These curves, along with yield tables, allow forest managers to choose what kind of silviculture is applicable in each case. However, the disadvantage with 

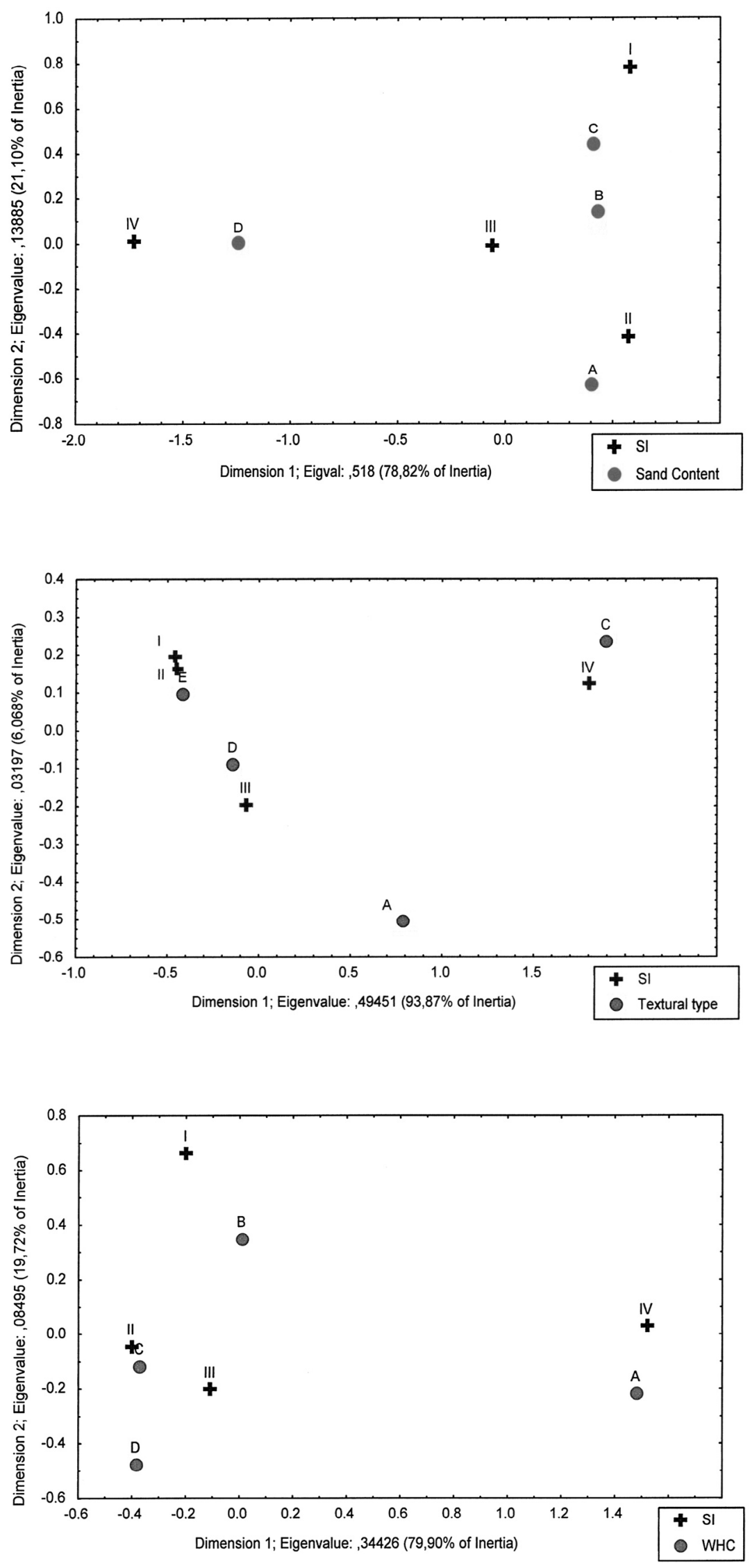

Figure 2. Perceptual maps. (a) SI vs. Sand content. (b) SI vs. Textural type. (c) SI vs. Water Holding Capacity. 
Table VII. Variation pattern and similarity index values between site index and categories of edaphic variables.

\begin{tabular}{|c|c|c|c|c|c|c|c|c|c|}
\hline \multirow{3}{*}{ Variable } & \multirow{3}{*}{ Category } & \multicolumn{8}{|c|}{ Site quality } \\
\hline & & \multicolumn{4}{|c|}{ Variation pattern } & \multicolumn{4}{|c|}{ Similarity index } \\
\hline & & I & II & III & IV & I & II & III & IV \\
\hline \multirow[t]{4}{*}{ Textural type } & A & 0.00 & 0.00 & 11.10 & 20.00 & -0.450 & -0.825 & 0.312 & 1.041 \\
\hline & $\mathrm{C}$ & 0.00 & 0.00 & 5.60 & 60.00 & -0.600 & -1.100 & -0.355 & 12.50 \\
\hline & $\mathrm{D}$ & 33.33 & 36.40 & 38.90 & 20.00 & -0.004 & 0.006 & 0.777 & -0.321 \\
\hline & $\mathrm{E}$ & 66.66 & 63.60 & 44.40 & 0.00 & 0.464 & 0.603 & -0.035 & -2.375 \\
\hline \multirow[t]{4}{*}{ WHC } & A & 0.00 & 0.00 & 11.11 & 60.00 & -0.750 & -1.375 & -0.027 & 9.025 \\
\hline & B & 66.66 & 36.36 & 27.77 & 40.00 & 1.361 & -0.003 & -0.453 & 0.008 \\
\hline & $\mathrm{C}$ & 33.33 & 45.45 & 44.44 & 0.00 & -0.027 & 0.185 & 0.231 & -1.875 \\
\hline & $\mathrm{D}$ & 0.00 & 18.18 & 16.66 & 0.00 & -0.750 & 0.284 & 0.250 & -0.625 \\
\hline \multirow[t]{5}{*}{ N_1h } & A & 0.00 & 0.00 & 0.00 & 20.00 & -0.150 & -0.275 & -0.450 & 6.125 \\
\hline & B & 16.66 & 0.00 & 0.00 & 0.00 & 4.816 & -0.275 & -0.450 & -0.125 \\
\hline & $\mathrm{C}$ & 0.00 & 0.00 & 5.55 & 20.00 & -0.300 & -0.550 & 0.011 & 2.250 \\
\hline & $\mathrm{D}$ & 0.00 & 18.18 & 44.44 & 20.00 & -1.650 & -0.347 & 1.879 & -0.102 \\
\hline & $\mathrm{E}$ & 83.33 & 81.81 & 50.00 & 40.00 & 0.416 & 0.656 & -0.450 & -0.405 \\
\hline \multirow[t]{4}{*}{ OM_1h } & A & 0.00 & 9.09 & 44.44 & 80.00 & -1.950 & -1.854 & 0.790 & 3.471 \\
\hline & B & 16.66 & 18.18 & 5.55 & 0.00 & 0.266 & 0.736 & -0.355 & -0.500 \\
\hline & $\mathrm{C}$ & 50.00 & 54.54 & 11.11 & 20.00 & 0.800 & 2.209 & -2.140 & -0.166 \\
\hline & $\mathrm{D}$ & 33.33 & 18.18 & 38.88 & 0.00 & 0.074 & -0.347 & 0.848 & -1.375 \\
\hline \multirow[t]{3}{*}{ Permeability } & A & 100 & 100 & 88.88 & 40.00 & 0.107 & 0.196 & 0.004 & -1.289 \\
\hline & B & 0.00 & 0.00 & 0.00 & 40.00 & -0.300 & -0.550 & -0.900 & 12.25 \\
\hline & $\mathrm{C}$ & 0.00 & 0.00 & 11.11 & 20.00 & -0.450 & -0.825 & 0.313 & 1.041 \\
\hline \multirow[t]{4}{*}{ Sand } & A & 0.00 & 45.45 & 22.22 & 0.00 & -1.350 & 2.576 & -0.001 & -1.125 \\
\hline & B & 50.00 & 36.36 & 27.77 & 0.00 & 0.800 & 0.148 & -0.029 & -1.500 \\
\hline & $\mathrm{C}$ & 50.00 & 18.18 & 22.22 & 0.00 & 2.016 & -0.091 & -0.001 & -1.125 \\
\hline & $\mathrm{D}$ & 0.00 & 0.00 & 27.77 & 100.00 & -1.500 & -2.750 & 0.055 & 11.25 \\
\hline \multirow[t]{4}{*}{$\mathrm{pH}$} & A & 33.33 & 0.00 & 0.00 & 20.00 & 5.338 & -0.825 & -1.350 & 1.041 \\
\hline & B & 0.00 & 36.36 & 5.55 & 0.00 & -0.750 & 5.011 & -0.694 & -0.625 \\
\hline & $\mathrm{C}$ & 50.00 & 36.36 & 44.44 & 40.00 & 0.079 & -0.097 & 0.016 & -0.007 \\
\hline & D & 16.66 & 27.27 & 50.00 & 40.00 & -0.694 & -0.306 & 0.750 & 0.008 \\
\hline
\end{tabular}

Table VIII. Discriminant analysis error rates found for qualities without grouping and grouped when crossvalidation is used.

\begin{tabular}{|c|c|c|c|c|c|c|c|c|c|c|c|c|c|c|c|c|}
\hline \multirow[t]{2}{*}{ Model } & \multicolumn{5}{|c|}{ Error found in four qualities } & \multicolumn{4}{|c|}{$\begin{array}{l}\text { Error found in three qualities } \\
\qquad(\mathrm{I}+\mathrm{II})\end{array}$} & \multicolumn{4}{|c|}{$\begin{array}{l}\text { Error found in three qualities } \\
\qquad(\mathrm{III}+\mathrm{IV})\end{array}$} & \multicolumn{3}{|c|}{ Error in two qualities } \\
\hline & I & II & III & IV & Total & $\mathrm{I}+\mathrm{II}$ & III & IV & Total & I & II & III + IV & Total & $\mathrm{I}+\mathrm{II}$ & $\mathrm{III}+\mathrm{IV}$ & Total \\
\hline 1 & 100 & 63.0 & 16.6 & 60.0 & 47.5 & 29.4 & 33.3 & 60.0 & 35.0 & 100 & 63.6 & 8.7 & 37.5 & 41.1 & 17.3 & 27.0 \\
\hline 2 & 100 & 63.6 & 11.1 & 60.0 & 45.0 & 64.7 & 61.1 & 60.0 & 62.5 & 100 & 63.6 & 4.3 & 35.0 & 70.5 & 34.7 & 50.0 \\
\hline 3 & 100 & 45.4 & 16.6 & 60.0 & 42.5 & 29.4 & 11.1 & 80.0 & 27.5 & 100 & 54.5 & 8.7 & 35.0 & 35.2 & 8.7 & 20.0 \\
\hline 4 & 100 & 54.5 & 11.1 & 80.0 & 45.0 & 41.1 & 16.6 & 80.0 & 35.0 & 100 & 54.5 & 8.7 & 35.0 & 47.0 & 8.7 & 25.0 \\
\hline 5 & 100 & 54.5 & 11.1 & 100 & 47.5 & 35.2 & 27.7 & 80.0 & 37.5 & 100 & 63.6 & 4.3 & 35.0 & 41.1 & 17.3 & 27.5 \\
\hline 6 & 100 & 54.5 & 22.2 & 20.0 & 42.0 & 35.2 & 44.4 & 20.0 & 37.5 & 100 & 45.4 & 8.7 & 32.5 & 41.1 & 26.0 & 32.5 \\
\hline 7 & 100 & 72.7 & 27.7 & 40.0 & 52.5 & 17.6 & 38.8 & 40.0 & 30.0 & 100 & 72.7 & 8.7 & 40.0 & 29.4 & 21.7 & 25.0 \\
\hline
\end{tabular}

Table IX. Discriminant rule for site index class in stone pine stands.

\begin{tabular}{lcc}
\hline \multirow{2}{*}{ Variable } & \multicolumn{2}{c}{ Groups } \\
\cline { 2 - 3 } & I + II & III + IV \\
\hline Constant & -8.7711 & -14.3613 \\
1/ELV & 534.460 & 691.884 \\
Ln(Silt) & 3.1624 & 4.3979 \\
$\sqrt{\text { clay }}$ & 1.1193 & 1.4045 \\
\hline
\end{tabular}

these curves is that they need a base age which is, in most cases, greater than stand age and, therefore, site index prediction is less accurate. Moreover, it is assumed that dominant tree height growth is independent of competition and that initial density has little influence on height growth [41]. However, other researchers suggest that initial density and growth are not independent, and try to correct that influence [33]. This is logical in young stands where classification with site index curves is more problematic. These problems have prompted researchers and managers to experiment with other site index prediction 
Model 3

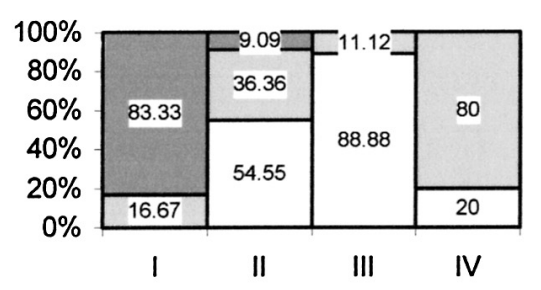

Model 7

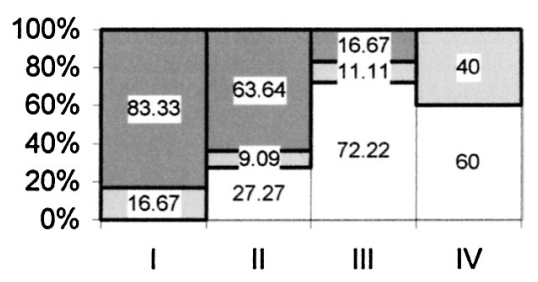

a) Four Site Index Classes
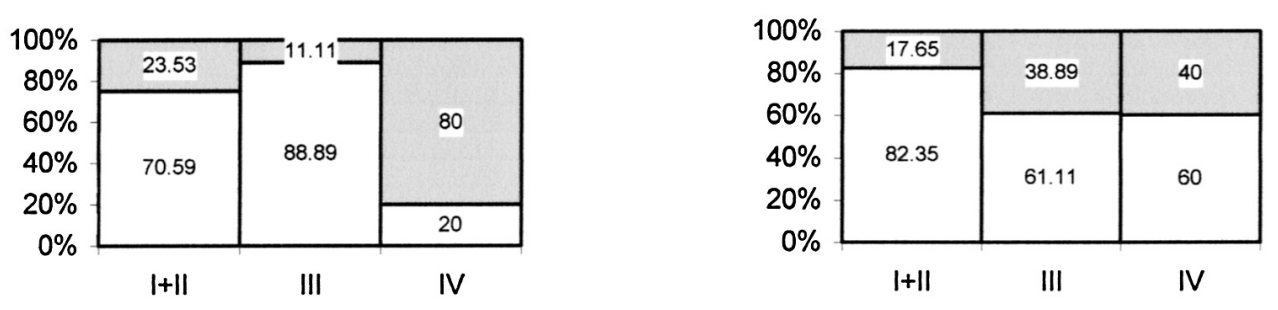

b) Site Index class I and II grouped
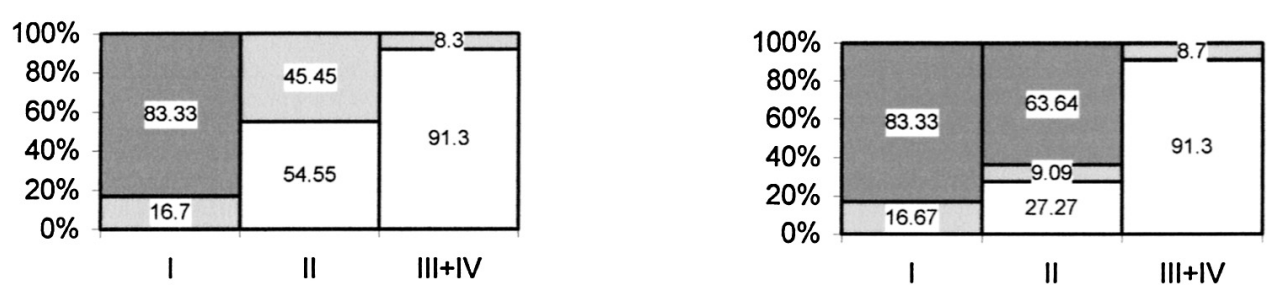

c) Site Index class III and IV grouped
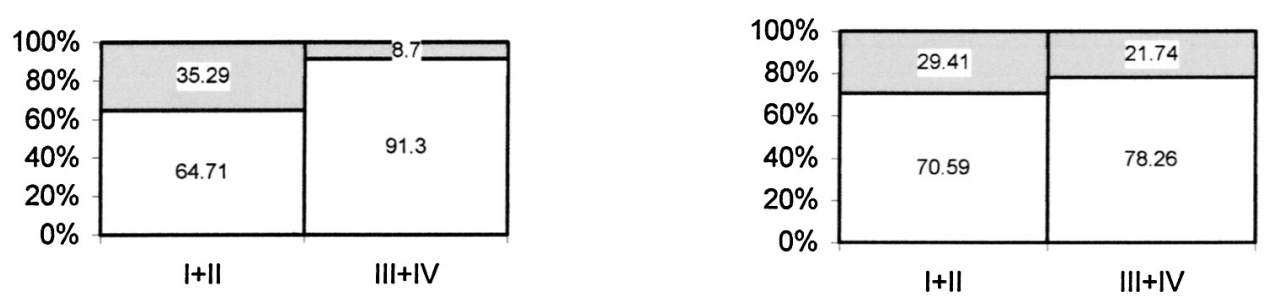

d) Two site quality groups

Correct classification

Adjacent classification

Non-adjacent classification
Figure 3. Classification percentages using cross validation for model 3 and 7. Percentages are divided into correct classification, classification in the adjacent site quality group or classification in non-adjacent group. 
methods, such as polymorphic curves [3], differential approach $[10,23]$ or indirect evaluation of site index from ecological variables [31, 51].

Ecological variables used in many site index studies are edaphic and climatic. Statistical methods find the relationship between these attributes and site index using multiple regression [50], principal components analysis [44], tree classification models [49], or discriminant rules [7].

This paper deals with two categorical methods, contingency tables and correspondence analysis, for displaying the association between site index classes and categories of edaphic variables. Then, a discriminant rule is applied in order to determine if the variables chosen in correspondence analysis may be used to classify new observations.

Two way contingency tables are the frequencies found for two categories. In this study, site quality classes and soil attributes have been cross-tabulated. The results indicate that variables related to texture, such as permeability or sand content are associated to site classes. In order to display these results, a correspondence analysis was performed.

Correspondence analysis is a variable ordination technique which is used as a preliminary inspection in any analysis [18]. Other authors have used it as a covariate pattern [46] and to determine site index along with vegetation communities [12]. In all cases, inertia axes are used as new variables, that account for most of the variance in the original variables, while reducing the dimension of the data. However, the capacity of correspondence graphics as perceptual maps has not been explored in forest studies.

In stone pine stands in south west Spain, the association between poor site classes, clay and impermeable textures is clear. Better sites are located in areas with higher sand content, and less clay and silt content, which is related to the autoecology of the species [6]. Contingency table analysis and perceptual maps from correspondence analysis are qualitative tools to determine what edaphic categories are most associated to site index classification. Variables found as good classifiers of observations into site quality are silt, clay and elevation. Silt and clay are related to texture, which is a key factor of forest growth in the Mediterranean area [7]. This factor was previously noted in the Correspondence Analysis.

Edaphic attributes do not discriminate good site classes from intermediates ones, probably due to the small number of plots in site index class I. However, class IV has a similar number of plots but it is differentiated from the other classes, most likely because texture affects growth on low quality sites. The discriminating effect of texture is shown in the contingency analysis, correspondence display and discriminant analysis. Factors other than soil attributes might explain the variation between site class I and the other classes.

McGrath and Loewenstein (1975) [35] state that elevation along with texture and other ecological parameters should explain site quality. Our discriminant model includes elevation which might be correlated to distance from the coast (lower areas being closer to the coast) because site index improves the further the stand is situated from the coast [36].

In this study, grouping is done according to site index class. Adjacent site index classes are grouped to develop a discriminant rule which may be used by forest managers to determine if a new plantation will have high production or not. It might be expected that the properties of a soil where there is no vegetation or, at most, a herbaceous cover would not be the same as those of a forest soil. Roots, litter and microclimatic conditions under a forest cover modify soil properties, so it is somewhat difficult to evaluate the potential productivity of a forest planted on bare soils due to the fact that the plantation will change these soil properties in the future. However, when a mature stand is located on soils of the reforestation type, with low parental rock flow, scarce differentiation in horizons and a narrow variation range of soil attributes, assessing forest productivity through soil attributes is greatly facilitated.

\section{CONCLUSIONS}

In edaphic environments with low variability, contingency analysis demonstrates the relationship between categories of soil attributes and site index. Graphical display of the Correspondence Analysis gives a perceptual variation pattern of site index classes according to categories of edaphic variables.

Discriminant analysis with site variables and, more precisely, with those related to texture and elevation is appropriate in stands of stone pine, although accuracy diminishes with an increase in the number of site classes. This fact must be taken into account when applying the model. The difference between groups of classes is higher than between individual classes, and a compromise between a low error rate and an adequate number of site qualities must be considered [7]. However, the grouped classes are important indicators in new plantations as well as in their future site index classification. Site class may help in defining what silviculture should be applied during the first years up to the moment when the stands reach base age. Quality assignation should be contrasted with the site curves developed by Montero and Ruiz-Peinado [38], considered more appropriate in older stands.

A better representation of plots according to site classes is needed in order to improve reliability, although discriminant analysis has been used with probabilities proportional to group size. Studies in this direction should be carried out in order to contrast this approach.

Finally, when observing error rates by groups, the poorest quality group is better classified. This leads us to believe that discriminant analysis is more sensitive to the least productive stone pine stands as they grow in clayey and silty areas near the coast. These stands can be classified correctly in two quality groups with less than a $29.4 \%$ error for the best quality and $21.7 \%$ error for the worst quality.

Acknowledgements: The authors wish to thank Miren del Río, Isabel Cañellas, Rafael Calama and Felipe Bravo for their comments on the manuscript and Sonia Roig for her help in drafting the abstract in French. Adam Collins made the revision of the English and we are deeply grateful. We also grateful to the anonymous referees for their comments on the manuscript.

\section{REFERENCES}

[1] Agresti A., Categorical data analysis, John Wiley \& Sons, 1990.

[2] Assmann E., The principles of forest yield study, Pergamon press, Oxford, 1971. 
[3] Bailey R.L., Clutter J.L., Base-Age invariant polymorphic site curves, For. Sci. 20 (1974) 155-159.

[4] Bara S., Toval G., Calidad de estación de Pinus pinaster Ait. en Galicia, INIA, 1983, Comuniaciones INIA, Serie Rec. For., 166 p.

[5] Benzécri J.P., Correspondence analysis handbook, Marcel Dekker, Inc., New York, 1992.

[6] Boisseau B., Écologie du pin pignon, Cemagref, Études Gestion des territoires, Annales Forêt 93 (1994) 173-188.

[7] Bravo F., Montero G., Site index estimation in Scots pine (Pinus sylvestris L.) stands in the High Ebro basin (northern Spain) using soil attributes, Forestry 74 (2001) 395-406.

[8] Calama R., Cañadas N., Montero G., Inter-regional variability in site index models for even-aged stands of stone pine (Pinus pinea L.) in Spain, Ann. For. Sci. 60 (2003) 259-269.

[9] Cañadas M.N., Pinus pinea L. en el Sistema Central (Valles del Tiétar y del Alberche): Desarrollo de un modelo de crecimiento y producción, Universidad Politécnica de Madrid, 2000, 356 p.

[10] Cao Q.V., Estimating coefficients of base-age-invariant site index equations, Can. J. For. Res. 23 (1993) 2343-2347.

[11] Carvalho A., Silvicultural practices on Pinus pinea in Portugal, INIA, Reunión sobre selvicultura, mejor y producción de Pinus pinea, 1989, $7 \mathrm{p}$.

[12] Casaubon E.A., Gurini L.B., Cueto G.R., Diferente calidad de estación en una plantación de Populus deltoides Cv. Catfish 2, del bajo delta bonaerense del río Paraná (Argentina), Inv. Agr. Sist. Rec. For. 10 (2001) 217-232.

[13] Chen H.Y.H., Krestov P.V., Klinka K., Trembling aspen site index in relation to environmental measures of site quality at two spatial scales, Can. J. For. Res. 32 (2002) 112-119.

[14] Ciancio O., Mercurio R., Criteria for the silviculture of Stone pine stands., Inv. Agr. Sist. Rec. For. Fuera de serie nº 3 (1994) 417-422.

[15] Cobertera E., Edafología aplicada, Ed. Cátedra, Madrid, 1993.

[16] Curt T., Bouchaud M., Agrech G., Predicting site index of Douglasfir plantations from ecological variables in the Massif Central are of France, For. Ecol. Manage. 149 (2001) 61-74.

[17] Daniel T.W., Helms J.A., Baker F.S., Principles of silviculture, McGraw-Hill, New York, 1979.

[18] Escudero A., Gavilán R., Rubio A., Una breve revisión de técnicas de análisis multivariantes aplicables en Fitosociología, Botanica Complutensis 19 (1994) 9-38.

[19] Gandullo J.M., Sánchez-Palomares O., Estaciones ecológicas de los pinares españoles, ICONA-Ministerio de Agricultura, Pesca y Alimentación, Madrid, 1994

[20] García Güemes C., Modelo de simulación selvícola para Pinus pinea L. en la provincia de Valladolid, Politécnica de Madrid, 2001, $225 \mathrm{p}$.

[21] García Güemes C., Cañadas N., Zuloaga F., Guerrero M., Montero G., Producción de piña de Pinus pinea L. en los montes de la provincia de Valladolid en la campaña 1996/1997, in: I Congreso forestal Hispano Luso / II Congreso Forestal Español, Pamplona, 1997, pp. 273-278.

[22] Gil J., García E., Rodríguez G., Análisis discriminante, MadridSalamanca, 2001.

[23] Goelz J.C.G., Burk T.T., Development of a well-behaved site index equation: jack pine in north central Ontario, Can. J. For. Res. 22 (1992) 776-784.

[24] Greenacre M.J., Theory and applications of correspondence analysis, Academic Press Inc., 1984.

[25] Hair J.F., Anderson R.E., Tatham R.L., Black W.C., Análisis multivariante, Prentice Hall Iberia, Madrid, 1999.

[26] Harding R.B., Grigal D.F., White E.H., Site quality evaluation for white spruce plantations using discriminant analysis, Soil Sci. Soc. Am. J. 49 (1985) 229-232.

[27] Holmgren P., Topographic and geochemical influence on the Forest Site Quality, with respect to Pinus sylvestris and Picea abies in Sweden, Scand. J. For. Res. 9 (1994) 75-82.

[28] Joaristi Olariaga L., Lizasoain Hernández L., Análisis de correspondencias, La Muralla S.A. and Hespérides, Madrid, 2000.
[29] Johnson R.A., Wichern D.W., Applied multivariate statistical analysis, Prentice Hall, Upper Saddle River, New Jersey, 1998.

[30] Júdez Asensio L., Técnicas de análisis de datos multidimensionales, Ministerio de Agricultura Pesca y Alimentación, Madrid, 1989.

[31] Klinka K., Carter R.E., Relationships between site index and synoptic environmental factors in inmmature coastal Douglas-fir stands, For. Sci. 36 (1990) 815-830.

[32] Legendre P., Legendre L., Numerical ecology, Elsevier, Amsterdam, 1998.

[33] Macfarlane D.W., Gree E.J., Burkhart E., Population density influences assessment and application of site index, Can. J. For. Res. 30 (2000) 1472-1475.

[34] Monserud R.A., Simulation of forest tree mortality, For. Sci. 22 (1976) 438-444.

[35] Monserud R.A., Moody U., Breuer D.W., A soil-site study for inland Douglas-fir, Can. J. For. Res. 20 (1990) 686-695.

[36] Montero G., Candela J.A., Ruíz-Peinado R., Gutierrez M., Pavon J., Bachiller A., Ortega C., Cañellas I., Density influence in cone and wood production in Pinus pinea L. forests in the south of Huelva province, in: IUFRO meeting on Mediterranean silviculture with emphasis on Quercus suber, Pinus pinea and Eucalyptus sp. Sevilla, 2000

[37] Montero G., Cañellas I., Selvicultura de Pinus pinea L. Estado actual de los conocimientos en España, in: I Simposio del Pino piñonero (Pinus pinea L.), Valladolid, 2000, pp. 21-38.

[38] Montero G., Ruíz-Peinado R., Curvas de calidad para Pinus pinea L. en el sur de Huelva, 2001 (unpublished)

[39] Nicolas A., Gandullo J.M., Los estudios ecológico-selvícolas y los trabajos de repoblación forestal, IFIE, 1966.

[40] Pacheco C., Evaluating site quality of even-aged maritime pine stands in northern Portugal using direct and indirect methods, For. Ecol. Manage. 41 (1991) 193-204.

[41] Pienaar L.V., Shiver B.D., The effect of planting density on dominant height in unthinned slash pine plantations, For. Sci. 30 (1984) 1059-1066.

[42] Ruiz-Maya L., Martín-Pliego J., López J., Montero J.M. ,Uriz P., Metodología estadística para el análisis de datos cualitativos, CISBCL, Madrid, 1990.

[43] Sabin T., Stafford S.G., Assessing the need for transformation of response variables, Forest Research Lab., 1990, Special publication, 20, $31 \mathrm{p}$.

[44] Sanchez-Rodriguez F., Rodríguez-Soalleiro R., Español E., López C.A., Merino A., Influence of edaphic factors and tree nutritive status on the productivity of Pinus radiata D. Don plantations in northwestern Spain, For. Eco. Manage. 171 (2002) 181-189.

[45] SAS Institute I., SAS/STAT User's Guide, Version 6, Vols. 1 and 2, SAS Institute Inc., Cary, NC, 1990.

[46] Schieck J., Suart-Smith K., Norton M., Bird communities are affected by amount and dispersion of vegetation retained in mixedwood boreal forest harvest areas, For. Ecol. Manage. 126 (2000) 239-254.

[47] Statsoft I., STATISTICA for Windows. Computer program manual, Tulsa, OK, Statsoft, Inc., 1995.

[48] Ter Braak C.J.F., Canonical correspondence analysis: A new eigenvector technique for multivariate direct gradient analysis, Ecology 67 (1986) 1167-1179.

[49] Verbyla D.L., Fisher R.F., An alternative approach to conventional soil-site regression modeling, Can. J. For. Res. 19 (1989) 179-184.

[50] Wang G.G., White spruce site index in relation to soil, understory vegetation, and foliar nutrients, Can. J. For. Res. 25 (1995) 29-38.

[51] Wang G.G., Klinka K., Use of synoptic variables in predicting white spruce site index, For. Ecol. Manage. 80 (1996) 95-105.

[52] Ximenez de Embrún J., Arenas movedizas y su fijación, Ministerio de Agricultura, 1960, Hoja divulgadora $\mathrm{n}^{\circ} 13-60 \mathrm{H}, 12 \mathrm{p}$

[53] Yagüe S., Producción y selvicultura del piñonero (Pinus pinea L.) en la provincia de Ávila, Producción, Montes 37 (1994) 45-51.

[54] Yagüe S., Producción y selvicultura del piñonero (Pinus pinea L.) en la provincia de Ávila, Selvicultura, Montes 36 (1994) 45-51. 